\title{
IS THERE A FUTURE FOR VERIFICATION AND CONCLUSIVE EVIDENCE ('VCE') CLAUSES IN AUSTRALIAN BANKING CONTRACTS?
}

\section{MARC ANDREW POSTHOUWER}

Lecturer College of Law and Justice, Victoria University, Melbourne, Australia

ABSTRACT
In certain jurisdictions, Verification and Conclusive Evidence ('VCE') clauses operate successfully in banking
contracts in order to protect the interests of banks in their dealings with their customers. The VCE clause has two
components: the verification component imposes a duty on the customer to verify account statement details, and the
conclusive evidence aspect declares that the information in the statement is deemed to be correct and incontrovertible
after a prescribed time.
The objective of this paper is to determine whether the use (or extended use) of VCE clauses can be justified in
Australian banking contracts.
This paper will provide an introduction to the nature and operation of VCE clauses in relation to bank account
and application.
KEYWORDS: Verification and Conclusive Evidence ('VCE'), Legislation \& Industry Codes

Received: Dec 30, 2016; Accepted: Jan 17, 2017; Published: May 17, 2017; Paper Id.: IJPSLIRJUN20171

\section{INTRODUCTION}

\section{Background}

This paper is derived from the author's preliminary work for a $\mathrm{PhD}$ proposal (under development) which seeks to determine the doctrinal basis and justification for the use of Verification and Conclusive Evidence ('VCE') clauses operating in Australian banking contracts, including those made with consumers and small businesses in relation to, inter alia e-payment systems, and to determine legal and policy issues affecting their current and future operation.

In Australia, the regulation of liability for unauthorised transactions on bank accounts varies according to the type of payment instrument used in the transaction. Customer duties and liabilities may be prescribed by common aw, legislation and/or industry codes.

Express terms are highly relevant to the banker-customer contract although their use in relation to consumers and small businesses is circumscribed by the industry codes and consumer protection legislation.

This paper will provide an introduction to the nature and operation of VCE clauses in relation to bank account statements and attempt to identify public and private law issues and economic policies that may influence or determine their scope and application. 


\section{The VCE Clause}

\section{Features $^{1}$}

The VCE clause operates as an express term of a contract and appears in a variety of commercial contexts including guarantees and construction contracts.

According to Loke, a VCE clause typically encompasses the following two duties:

First, the customer assumes contractual responsibility for examining and verifying the statements sent by the bank. Second, the customer agrees to notify the bank of any errors or inaccuracies in the statements. Upon the expiry of the contractually stipulated period for raising inaccuracies with the bank, the conclusive evidence clause renders the statement conclusive of the amounts owing between the bank and its customer. Importantly, the customer is precluded from raising questions relating to inaccuracies in the statements. ${ }^{2}$

The verification component imposes a duty on the customer to verify statement details and the conclusive evidence aspect declares that the information in the statement is deemed to be correct and incontrovertible after a prescribed time ${ }^{3}$.

Under the clause, 'timely objection is required to be made in writing by the customer within a prescribed period, failing which, the account statements are by their terms conclusive against the customer in respect of the matters reflected in them'.

Non-compliance with the duty means that a customer will be barred contractually in accordance with time constraints from impugning the account statement on grounds of a transaction being unauthorised. In reliance on the clause, the bank may deny rectification of the account without the need to prove loss to it.

The clause gives finality to transactions and indirectly allocates losses between the customer and bank.

The duties of customers may be divided between those occurring before and after the unauthorised transaction. Examples of pre-transaction liabilities involve failure by the customer to safeguard their PIN or password or to notify the bank of the loss or theft of a card, while post-transaction liability involve omissions to notify the bank of unauthorised transactions within a prescribed time. (Notification obligations are highly significant in pre-transaction situations as prompt action by the customer in informing the bank of loss theft of a card, or compromise of a password, can minimise harm. In the jurisdictions mentioned below there is tiered capping of liability). In the case of payment instruments, the VCE clause addresses the customer's obligations after the unauthorised transaction has occurred- in other words, post-transaction liability.

\footnotetext{
${ }^{1}$ The author wishes to thank his PhD supervisors, Professor John Glover and Dr Andrew Vaitiekunas of the Graduate School of Business and Law, RMIT, Melbourne, for their assistance in developing this research proposal which is the subject of this paper.

${ }^{2}$ F H Loke, 'Framing Contractual Freedom within the precept of Honesty, Reliability and Integrity', (2012) Singapore Journal of Legal Studies $174,176$.

${ }^{3}$ E P Ellinger, E Lomnicka, and C Hare, Ellinger's Modern Banking Law ( Oxford university Press, 5th ed, 2009), 244

${ }^{4}$ Mohamed Baiross, 'Conclusive Evidence Clauses in the Court of Appeal: Pertamina Energy Trading Ltd v Credit Suisse', (2007) 25 Singaore.Law.Review 136, 137.
} 


\section{CONTROVERSIAL FEATURE}

The use of VCE clauses is controversial because it enlarges the scope of customer's duty to examine bank statements when no such duty exists under common law. Furthermore, it applies to errors in bank statements of which customers may not even be aware, and, significantly, it precludes a customer from objecting to a debit on its account procured by fraud.

\section{LEGAL EFFECT OF ACCOUNT STATEMENTS AND RECTIFICATION}

An examination of the nature and operation of VCE clauses, and the rationale for their use require an analysis of the legal significance of bank statements and the scope for rectifying any errors they contain.

Periodic bank statements may contain inaccuracies resulting from computational errors or from wrong entries. In cases where the bank credits the customer's account with the wrong amount or with a sum not due to the customer, the bank can, on discovering the error, reverse the entry. This right is based on the principle that a person who pays money to another without reason usually acts under a mistake. Therefore, the payer should be entitled to recover the amount involved by bringing an action in restitution, or by applying for a declaration that the amount involved was not due. ${ }^{5}$ The circumstances in which the customer may dispute the bank's right to do so are where the balance constitutes an 'account settled' or an 'account stated' or where the bank is estopped from disputing the correctness of the balance as shown in the periodic statement.

In relation to 'account stated', the plea that a periodic account statement constitutes an 'account stated' may be raised either by the bank or the customer in an effort to deny the other the right to have an error or wrong entry rectified.

When an account is stated, it becomes similar to a confirmation by a debtor that the creditor is claiming the correct amount. The plea has been described as a 'convenient legal fiction which avoids the necessity, if recourse has to be had to legal proceedings, of suing upon individual items in the account'. ${ }^{6}$ In the case of a current account, the customer and the bank would lose the right to query the correctness of the given items once the bank statement becomes an'account stated' 7 .

However, English law has refused to regard the statement in this way: In Kepitigalla Rubber Estates Ltd v National Bank of India Ltd. ${ }^{8}$ The customer is entitled to demand rectification of entries in its account after a lapse of reasonable time from the date of receiving the bank statement for the reason that the law has generally refused to regard a customer's bank statement as constituting an 'account stated" ${ }^{9}$ and in the absence of fraud, the customer is not precluded by the bank statement from disputing the error or incorrect debit made by the bank or from insisting upon its correction. ${ }^{10}$

\footnotetext{
${ }^{5}$ Ellinger, Lomnicka, and Hare, above n 3, 246.

${ }^{6}$ Ibid 300.

${ }^{7}$ Ibid 247.

${ }^{8}$ [1909] 2 KB 1010

${ }^{9}$ Ellinger, Lomnicka, and Hare, above n 3, 244.

${ }^{10}$ Ibid 236.

www.tiprc.org
}

editor@tjprc.org 
The justification for this refusal seems to turn on the view that the purpose of bank statements is to inform the customer of account movements and not to benefit the bank. This is supported by Tai Hing Cotton Mill Ltd v Liu Chong Hing Bank Ltd ${ }^{11}$ (discussed below) which emphatically rejected an implied duty on a customer to examine bank statements and report errors to the bank. The case emphasised the bank's duty to comply with its customer's mandate, and where it is absent, for example where a cheque that has been fraudulently drawn or altered with a resulting debit to the customer's account, as a general rule the customer is entitled to seek rectification of its account. A significant exception arises where the customer knows that an entry in the statement of account is wrong and keeps silent; it will be precluded from asserting the error once the bank has changed its position. ${ }^{12}$ As will be seen, the exception depends on actual knowledge of the customer which is not always present to allow a bank to deny rectification.

As for the second circumstance allowing for rectification, estoppel will be invoked by the customer where an error has lulled the customer into a false belief about its financial position and if the customer has changed its position to its detriment, the bank may find itself precluded from reversing the entry. ${ }^{13}$ Estoppel can only be pleaded if the customer was misled or had reason to be misled by the erroneous balance. ${ }^{14}$

\section{CUSTOMER'S COMMON LAW DUTIES}

Under the common law, a bank has no mandate to pay on a forged instrument of a customer. ${ }^{15}$ If such a payment is made, it is liable to its customer, subject to established exceptions detailed below.

Banks have two established defences against a customer's claim for breach of mandate for debiting their account on the basis of a forged instrument. Although operating as defences, the courts have described and characterised the following as implied 'duties' of the customer, ${ }^{16}$ namely:

- Duty to notify bank promptly of forged cheques purported to have been signed by customer when customer becomes aware of forgeries. ${ }^{17}$ This duty extends to notification of any unauthorised transactions on the account which become known to the customer. ${ }^{18}$

- Duty to exercise reasonable care in drawing cheques so that the banker is not misled and forgery is not facilitated. $^{19}$

It is an open question whether banks owe a wider duty of care in operation of accounts ${ }^{20}$, but the landmark decision of the Privy Council in Tai Hing Cotton Mill Ltd v Liu Chong Hing Bank Ltd ${ }^{21}$ appears to have limited the scope of these implied duties. Consequently, wider duties that have been rejected by the courts include the duty to discover forgeries; the duty to take reasonable care in safekeeping a cheque book; and the duty to organise one's business in such a way to safeguard the interests of the bank. ${ }^{22}$

\footnotetext{
${ }^{11}$ [1986] 1 AC 80

${ }^{12}$ Greenwood v Martin's Bank Ltd [1933] AC 51

${ }^{13}$ Skyring v Greenwood and Cox (1825) 4 B \& C 281

${ }^{14}$ British and North European Bank Ltd $v$ Zalstein [1927] 2 KB 92, 287

${ }^{15}$ Greenwood v Martin's Bank Ltd [1933] AC 51.

${ }^{16}$ For example, Tai Hing Cotton Mill Ltd v Liu Chong Hing Bank Ltd [1986] AC 80.

${ }^{17}$ Ellinger, Lomnicka, and Hare, above n 3.

${ }^{18}$ See the cases of West v Commercial Bank of Australia Ltd (1935) 55 CLR; Klement v Pencoal(2000) ConvR 54-546.

${ }^{19}$ London Joint Stock Bank Ltd v Macmillan and Arthur [1918] AC 777 (known as the 'Macmillan duty').

${ }^{20}$ Halsbury's Laws of Australia online, [45-795].

${ }^{21}$ [1986] 1 AC 80

22 Ibid.
} 
These restrictions in Tai Hing have been the subject of criticism, not least, relating to the legal position that the banker-customer contract does not impose a duty on a customer to read the bank statement or to discover errors in it. ${ }^{23}$

One way in which banks have sought to modify these limited implied duties is through the use of VCE clauses by which banks attempt to impose a duty on the customer to read the bank statements, vouchers and receipts and to notify the bank within a certain time of any error. Thus, through the use of VCE clauses, customers are bound by a contractual duty to check their statements, failing which, the banks can rely on the provision to exclude their liability for any unauthorised debit of the customer's account. ${ }^{24}$

Although not commonly used in Australia or the United Kingdom, at least in relation to consumer banking contracts, the use of such clauses has been the practice in Canada for over 60 years where Canadian law follows the common law in holding there is no duty to verify in the absence of such clause. ${ }^{25}$ In the United States, the statutory equivalent of the VCE is contained in section 4-406 of the Uniform Commercial Code which imposes a 'duty' on the customer to discover and report unauthorised signatures or alterations. If customers fail to comply with this duty, they are precluded from disputing the regularity of the payments made.

The VCE clause has the effect of reversing not only the common law rule set out in Tai Hing, but also changes the incentives of the customer by providing an inducement for the customer to carry out periodic internal audits of its finances within the specified time period otherwise, a lapse in checking the accuracy of the bank statements could result in financial losses being borne by the customer. ${ }^{26}$

These diverse jurisdictional approaches require further examination in the proposed thesis

\section{MODELS OF VCE CLAUSES AND THEIR VARIANTS}

There are variants of the VCE clause that present different legal models applicable to their operation. The possible forms the clause might take are where there is a verification duty only; or a verification and notification duty without specifying any time period in which the verification must be undertaken and errors reported; or verification and notification duty with the presence of a conclusive evidence element - the fully fledged VCE clause. The operation and efficacy of the first two types of clauses require further examination.

The viability of a stand-alone verification clause (without the support of the conclusive evidence component) has been analysed by Booysen who has dismissed a truncated clause as ineffective and illusory, either as adefence or counterclaim by a bank due to difficulties of establishing causation -] that a customer's breach of verification duty is the cause of loss rather than the bank's own breach of mandate. ${ }^{27}$

\section{Public Policy}

A question arises as to whether there are public policy grounds for impugning the validity of a VCE clause due to its conclusive effect. The leading English case of Bache \& Co v Banque Vernes ${ }^{28}$ did not concern a current account but a bank guarantee which contained a term that stated that notice of the borrower's default to the guarantor (in this case, a

\footnotetext{
${ }^{23}$ Christopher Hare, 'The duties of bank customers: W(h)ither Tai Hing?' (2012) 23 JBFLP 182.

24 Ibid.

${ }^{25}$ A Tyree and J Sheahan, 'Verification Clauses', (2010) 23 JBFLP 291.

${ }^{26}$ Ibid.

${ }^{27}$; S Booysen, 'Bank Documentation: The Standard Terms governing Current Accounts in Singapore; The Customer's Duty of Care, the Unauthorised debit and Allocation of Risk',(PhD Thesis, National University of Singapore 2008) $161,186$.

${ }^{28}$ [1973] 2 Lloyd's Rep 437 
bank) was conclusive as to the amount of the bank's liability to the holder of the guarantee. The Court of Appeal rejected the argument that the clause was contrary to public policy for ousting the jurisdiction of the court. The court referred to the Australian decision of Dobbs $v$ National Bank of Australasia Ltd ${ }^{29}$ which drew a distinction between a clause denying access to the courts and one that set out a method to ascertain rights or facts. Lord Denning stated in Bache that the use of the conclusive evidence clause was 'only acceptable because the bankers or brokers who insert them are known to be honest and reliable men of business who are most unlikely to make a mistake'. ${ }^{30}$

\section{Economic Approaches}

An economic analysis of VCE clauses can begin with an overview of economic principles governing payment systems and risk management. This approach contributes to insight into the workings of the payment system as a market, and therefore identifies factors driving the decisions of the key participants (including banks, card issuers, payment network intermediaries, merchants and end users) to formulate and apply loss allocation rules. If a key function of a VCE clause is to provide a loss-allocation mechanism, its presence or absence in various jurisdictions would seem to depend on economic assumptions about their utility for loss allocation in the payments system. Such analysis assists in resolving the related questions concerning their doctrinal justification and effectiveness in relation to a range of payment systems spanning both electronic and non-electronic instruments.

\section{Payment System Information}

All payment systems can be viewed as systems for managing valuable information. They keep records of transactions and communicate transaction data. Any information stored and transmitted by a payments system can be described as an economic good, an item having value in exchange. ${ }^{31}$ Although this characterisation is at odds with its legal classification as intangible property or a chose in action, payment data is nevertheless depicted by Braun et al as a product, specifically, non-rival in nature in that, like intellectual property, it can be reproduced and consumed without diminution.

Central to its value is data integrity so that its usefulness can be diminished by fraud or security breaches or even operational disruptions that make it difficult to transmit data. Data security risk can be seen as operational risk that may facilitate fraud, unauthorised transactions or identity theft.

Payment security is a jointly produced club good because it is the result of joint efforts by all participants - not just entities in the supply chain but also end users. ${ }^{32}$ The contributions of each participant is a function of other participants and is therefore one of interdependency. Without proper co-ordination of participants, there is potential for system failure.

Competing service providers have incentives to mitigate risk because system failure will lead to their extinction or diminution in the market place.

\footnotetext{
${ }^{29}[1935]$ HCA 49

${ }^{30}$ [1973] 2 Lloyd's Rep 437

${ }^{31}$ Michele Braun et al, 'Understanding Risk Management in Emerging Retail Payments', (September 2008) FRBNY Economic Policy Review, $137,141$.

${ }^{32}$ Fumiko Hayashi, Tyler Moore and Richard Sullivan, 'The Economics of Retail Payment Security' (2015) FRBK Economic Policy Review, 1, 6.
} 


\section{Characteristics of a Retail Payments Market}

Retail payments markets can be characterised by network externalities, two-sided markets, and economies of scale and scope. $^{33}$

A network externality refers to a situation where the value of a product or service for an individual or consumer is dependent on the number of consumers using it. For example, as more people adopt ATMs, more ATMs may be deployed, encouraging more consumers to use them, and thus the value of an ATM service increases for each individual consumer. This critical mass is encouraged further by other network providers providing interoperable services, allowing customers of alternative providers to exchange payment with each other. ${ }^{34}$

A two-sided market occurs when end users are divided into distinct groups. In a payment market, one side consists of users who are payees, such as merchants, and the other side are payers, such as consumers. Externalities apply to this market because the decisions of one side of users affects the value of the product or service to the other side of users. Usage of an established payment method can occur when a consumer's choice of payment method affects the merchant's cost and benefit from the transaction. For example, a consumer's selection of payment method usually does not take into account the merchant's cost or benefit from the transaction, unless there is a mechanism to incorporate the merchant's cost or benefit, such as surcharges of discounts. ${ }^{35}$

Economy of scale refers to a system of production whose capital investment often yields increasing returns to scale. Multiple payments can be supported by integrated infrastructure. The presence of large economies of scale and scope may result in concentration of market power and inhibit entry of new players. ${ }^{36}$ It also has potential for anti-competitive behaviour and imposition of loss allocation rules that are unfavourable to consumers.

\section{Management of Payment Risks}

Service providers have developed three broad approaches to managing various kinds of payment risk: pricing, insurance and containment. $^{37}$

Pricing means that a party that bears a risk is compensated appropriately. Where credit is involved, it occupies a central role in allocating credit risk and is manifested in charging higher fees or interest rates for subprime borrowers. ${ }^{38}$ However, pricing is dependent on known and quantifiable risks, and where these are lacking or asymmetric, adverse selections may result. For fraud risk, the effectiveness of pricing is limited because in the case of credit card issuers, they do not seek to recover costs through differentially higher fees or interest rates by imposing higher tariffs on cardholders likely to commit fraud. Asymmetric information ${ }^{39}$ arises in which one party to a transaction has more or superior information than the other. In a payments system, asymmetry may be manifested in various ways. For example, a security product may be superior to another, but if potential buyers or users cannot verify it, suppliers of security products have little incentive to produce a superior product.

It may arise in relation to the reporting costs to service providers of fraud or data security incidents. Many

\footnotetext{
${ }^{33}$ Ibid 3.

${ }^{34}$ Ibid 5.

35 Ibid.

${ }^{36}$ Ibid 6.

${ }^{37}$ Braun et al,above n 31, 143.

${ }^{38}$ Ibid 143

${ }^{39}$ Hayashi et al,above n 32, 9. 
industry participants may have an incentive to underreport those incidents for fear of frightening away customers using certain payment methods, or because of reputational risk. ${ }^{40}$ On the other hand, vendors of security products may have an incentive to overstate aggregate losses in the industry in order to promote sales.

The lack of in information about the true cost of fraud and data security incidents prevents the industry participants from accurately understanding threats and defences. ${ }^{41}$ This lack of information will impact on pricing because security investments may not be properly distributed across appropriate defences.

Insurance is an agreement about who bears loss when one occurs. For example, a merchant receiving a credit card payment is insured against risk that the cardholder will not be able to pay the balance; or a customer who been the victim of credit card fraud may be effectively insured against fraudulent transactions. ${ }^{42}$

The major limitation of insurance is the effect of moral hazard which has a significant impact on incentives and behaviour of the insured party. ${ }^{43}$ Moral hazard occurs when one party assumes more risks because another party assumes the burden of those risks. This can lead to opportunistic behaviour on the part of the insured at the expense of the insurer, and result in improper allocation for fraud losses or data breaches which discourages security investments made by parties that are best positioned to control security. ${ }^{44}$

From the viewpoint of the payment system provider, the functioning of pricing and insurance may be affected beneficially or adversely by the respective presence or absence of VCE clauses. A VCE clause may reduce costs to the payment system provider, and hence, the price it charges for its services. Conversely, it may increase costs substantially for the consumer in terms of compliance. Furthermore, it can be seen as reducing the level of available 'insurance' to a customer by denying rectification of the account after the lapse of specified time. Globally, it may negatively impact on service provider's market share if there is little or no uptake of such clauses by its competitors, thus failing to achieve its own critical mass.

Containment consists of activities that deter or suppress risk, for example, by imposing authentication and identification procedures on merchants when accepting credit cards. Containment incentives can be provided by a system of monitoring participants and imposing penalties for inadequate risk controls that lead to significant losses or disruptions. $^{45}$

This definition of containment could be adapted to extend verification duties to consumers so as to justify the utilisation of VCE clauses thereby contributing to systemic mitigation of fraud and operational risks.

\section{Diverse Loss-Allocation Approaches}

It has been argued that advances in payment system technology present a challenge to define the most socially beneficial roles to assign to public law and private law and that the public law of payments is best limited to prevention of oppression, fraud and mistake 'victimising' end-users. ${ }^{46}$

In the United States, disparities between rules governing different payment instruments have been criticised in

\footnotetext{
${ }^{40}$ Ibid 10.

${ }^{41}$ Ibid.

${ }^{42}$ Braun et al, above n 31, 143.

${ }^{43}$ Ibid.

${ }^{44}$ Hayashi et al, above n 32, 10 .

${ }^{45}$ Braun et al, above $n$ 36, 143-4.

${ }^{46}$ Mark Burge, 'Apple Pay, Bitcoin and Consumers', (2016) 67 Hastings LJ 1493.
} 
legal literature as lacking coherence and consistency ${ }^{47}$. For example, Gillette and Walt have questioned why regulations affecting functionally equivalent payment systems vary in form and substance on questions of liability for unauthorised payments. ${ }^{48}$ They suggest a range of alternative explanations based on public choice, historical inertia, or discrete differences between the systems, none of which, in their view, provide adequate explanation. These concerns have also been expressed by Facciollo who has identified different customer-banker liabilities for unauthorised banking transactions depending on whether they are affected by cheque, cards (debit or credit card) or Automated Clearing House instructions. 49

In examining the justification for public and private law fraud liability rules, in context of the U.S payment card schemes, attention has been given to the broader question of whether the rules create incentives that minimise system wide fraud losses. According to Douglass, the default position is that consumers rarely bear meaningful liability for fraudulent transactions unless they benefited from the fraud. ${ }^{50} \mathrm{He}$ argues that card network 'zero liability' policies (and even very low deductibles payable under public law leave in place significant moral hazard).

Douglass identifies two significant challenges that would prevent changes to this liability rule. The first of these is the trend among legislators to favour consumer protection regardless of efficiency of fraud-related outcomes these laws produce. The second is based on the proposition that broad based user adoption of any payment system depends on confidence in system's security and safety. A system that increases cardholder liability for fraudulent transactions would discourage confidence of end users and therefore, increased cardholder liability would not be a viable option for improving overall efficiency of fraud allocation rules. ${ }^{51}$

While economic approaches have been identified as possible bases for different loss allocation rules according to type of payment system, there is the view that any loss-allocation rule should provide incentives to the party best able to prevent the unauthorised transaction at the lowest cost ( the 'least-cost avoider' principle). Cooter and Rubin have identified the loss allocation rule as being based on the three economic principles of loss spreading, loss reduction, and loss imposition. $^{52}$

Kahn and Roberds have examined these principles in relation finality of payment in relation to divergent payment systems. In their analysis, these systems' different finality rules imply different risk allocations among the participants though they concede that one set of finality rules is not necessarily better than another in all situations. In the case of cheques, they view their finality of payment as quite tentative due to the need for the payment to be settled between the paying and collecting banks, and risks are often concentrated on a single party. In applying the least- cost avoider principle to rules governing indorsement and drawing of cheques, they assess allocation of liabilities in terms of assumed knowledge of relevant parties. ${ }^{53}$

\footnotetext{
${ }^{47}$ S Harris, 'Introduction to Rethinking Payments Law', Chicago-Kent Law Review, (2008) Vol 83:2, 477.

${ }^{48}$ C Gillette and S. Walt, 'Uniformity and Diversity in Payment Systems', Chicago-Kent Law Review, ( 2008) Vol 83:2, 499.

${ }^{49}$ F. Facciollo,'Unauthorised Payment Transactions and Who Should Bear the Losses', Chicago-Kent Law Review, (2008) Vol 83:2, 605.

${ }^{50}$ D. Douglas, 'An examination of the fraud liability shift in consumer card-based payment systems', (1

Q 2009) FRBC Economic Perspectives 43, 46.

${ }^{51}$ Ibid.

${ }^{52}$ R.Cooter and E.Rubin, 'A Theory of Loss Allocation for Consumer Payments', (1987) 66 Tex. Rev 63.

${ }^{53}$ C.Kahn and W.Roberds, 'The Economics of Payment Finality', (2002) Federal Reserve of Atlanta Economic

Review 10
} 


\section{Economic Approaches to VCE Clauses}

The application of economic models to VCE clauses takes into account the economic principles identified above and in this part, relates them to a simple banker-customer model with reference to comparisons between pre-transaction and post-transaction liabilities. (At this point, no attempt is made to undertake a comparative analysis of different payment jurisdictions applying loss allocation rules to diverse payment methods).

On the issue of pricing, banks set fees and charges for their services and products, taking into account costs to themselves of adjusting the financial consequences of unauthorised transactions to their customers. The pricing structure addresses information asymmetry relating to unauthorised transactions by the bank requiring its customer to report promptly the loss or unauthorised use of their payment instruments (such as cards or cheque books) or the compromise of access codes such as PIN numbers. By imposing these pre-transaction duties, the bank establishes a containment mechanism by its ability to limit further unauthorised access to the customer's account and also enhances monitoring by the bank. This benefits both the bank and its customer. A customer is given an incentive to comply with this contractual obligation or else suffer the actual losses that occur until notification takes place, while the bank has an incentive to react quickly to the customer's notification.

Where the customer complies with its pre-transaction duties it is effectively insured by the bank against losses from unauthorised transactions, with the bank bearing the loss. The customer's reporting obligation also reduces the risk of moral hazard by rendering the availability of such insurance conditional on satisfying that reporting obligation. The economic cost to the customer should be minimal only requiring it to exercise reasonable vigilance in taking care of its payment instruments and access codes, and where necessary, reporting the prescribed incident. By these means, the 'club good' of payment security is enhanced, reducing the cost of insurance borne by other customers of the bank in the form of higher fees reflecting higher premiums, and the cost borne by the bank in compensating its customers for actual losses or being required to charge higher fees making it less competitively attractive.

In the realm of post-transaction liability, the VCE clause also imposes a reporting obligation within prescribed time limits set by the bank but this time in relation to transactions that have already occurred, and which may be unauthorised. There are similarities with the application of pre-transaction models in relation to pricing, but the cost, borne by the customer, now appears to be greater due to the time and effort required to check its statements. The clause also addresses information asymmetry by mandating notification of discrepancies detected in the bank statement. It can also be seen as serving as containment of risk of undetected unauthorised transactions by imposing monitoring duties on the customer, so as to enhance the bank's overall monitoring capacity.

Incentives to comply with verification and notification duties operate differently in that if a customer complies within the set time limit, the unauthorised transaction will need to be reversed by the bank, with the loss falling on the bank. If the customer does not comply, the bank statement's conclusiveness precludes further disputation and adjustment in the customer's favour. Here, the loss falls squarely on the customer. As with pre-transaction incidents, the insurance principle operates in favour of both parties in terms of reduced fees, but in the case of non-compliance with VCE clauses, the potential loss to the customer appears to be far greater.

Assuming that the customer can be seen as receiving some degree of insurance where it does comply with the notification duty the clause may reduce the risk of moral hazard on the part of customer. However, the question may also 
be asked of the bank- whether the VCE clause creates moral hazard on its part by shifting risk of loss to a non-compliant customer- thus giving the bank less incentive to ensure the accuracy of its bank statements or to enhance its containment practices.

\section{Norms of Consumer Protection}

VCE clauses override the common law position in Australia that customers do not have any obligation to examine and verify their account statements in the absence of express provision in the banker-customer contract. Where a VCE term is present, it would need to pass muster under consumer protection legislation dealing with unfair terms.

The issue of whether VCE clauses in Australia breach consumer protection laws dealing with unconscionable behaviour of unfair contract terms legislation (UCTL) remains untested by the courts although there are plentiful examples of countries with robust consumer protection regimes that do permit the use of such clauses in consumer banking contracts, providing an indication that there may well be policy and legal justifications for Australian banks to follow similar models

However, before examining the relevant Australian legislation it is worth highlighting indications of concern relating to the use of these clauses from a number of sources, including Consumer Affairs Victoria which has made the following comments in relation to the s4(1)(1) Australian Consumer Law ( the counterpart of s12BH(1)(1) of the ASIC Act ) 54 :

A term, such as a conclusive evidence term, is likely to be unfair under the Provisions [of the Australian Consumer law]. A conclusive evidence term is a term that stipulates that documents produced by one party to the contract (for example, invoices of amounts owing issued by the business) are prima facie evidence of their contents. These terms may have the effect of deterring a consumer accessing legal remedies.

In its submission to Treasury, the Australian Consumers' Association (as it then was) listed examples of allegedly unfair terms, including conclusive evidence clauses, stating ${ }^{55}$

Clauses that confer a particular evidentiary value upon certificates or other documents issued or held by lenders or third parties are frequently used in standard loan and security agreements. Generally, such clauses may be acceptable where they do no more than create a presumption - which it is open to being rebutted - that information contained in the lender's certificate or other document is accurate ('sufficient' or 'prima face' evidence clauses). However, some evidence clauses go further and attempt to deny or greatly restrict the consumer party's ability to challenge information contained in certificates and other documents etc ('conclusive' evidence clauses). Although conclusive evidence clauses have been extensively criticised by the Courts as being unnecessary to protect the legitimate interests of finance providers, they continue to be found in consumer credit and security contracts.

The possibility of VCE clauses being invalidated by consumer protection legislation in Australia has been raised by Tyree. $^{56}$

\footnotetext{
${ }^{54}$ A guide to the unfair contract terms law (2010) [4] Victorian Consumer Affairs < http://www.consumer.vic.gov.au/CA256EB5000644CE/page/Listing-Utility+Buttons>

${ }^{55}$ <www.treasury.gov.au: ACA submission Annex II: Examples of Unfair Terms in Consumer Contracts>

${ }^{56}$ A Tyree has commented that 'There remains the possibility that a verification clause covering a consumer account would be declared void under the Unfair Contract Terms of the Australian Consumer Law' in banking law and banking practice; see (2012) JBFLP 291, 293 


\section{Unfairness}

This section provides a brief background to the Australian legislation under which VCE clauses may be challenged.

In Australia, the principal UCTL affecting the banking sector is the ASIC Act 2001 (Cth) which regulates unfair contract terms in consumer contracts involving financial services. The Act defines a consumer contract as a contract at least one of the parties to which is an individual whose acquisition of what is supplied under the contract is wholly or predominantly an acquisition for personal, domestic or household use or consumption. ${ }^{57}$ This definition requires the courts to consider the actual purpose- not the price, or ordinary purposes for which financial products or services are acquired. Furthermore, the contract must be a standard form contract defined in s $12 \mathrm{BK}$ and understood to be one which is offered to the consumer on a take it or leave it basis. ${ }^{58}$ However, even where such a contract exists, there are some terms such as upfront price that remain unaffected by the unfair contract term provisions. ${ }^{59}$

A recent legislative amendment ${ }^{60}$ extends the application of the unfair terms provisions to a standard form small business contracts.

Under s12BF(1) of the ASIC Act a term of a standard form consumer contract is void if it is unfair. The section lists three criteria for establishing unfairness in relation to a standard form consumer contract as follows:

- It would cause a significant imbalance in the parties' rights and obligations arising under the contract; and

- It is not reasonably necessary in order to protect the legitimate interests of the party who would be advantaged by the term; and

- It would cause detriment (whether financial or otherwise) to a party if it were to be applied or relied on.

Under ASIC Act s $12 \mathrm{BG}$ (4) a term is presumed not to be reasonably necessary and the party advantaged by term must prove otherwise

For the purpose of determining unfairness under this test, a court may take into account such matters as it considers relevant ${ }^{61}$ and must take into account the extent to which the term is transparent, and the contract as a whole. ${ }^{62}$

The legal literature reviewed so far explains this three-part test abstractly referring to a narrow range of case examples, none of which address conclusive evidence clauses. The extrapolation of this test will be a focus of further examination in this thesis.

Explications of the provision's threshold test have been by reference to case examples mostly applicable to contracts for supply of goods and non-financial services, none of which address conclusive evidence clauses in financial services contracts. ${ }^{63}$ To date, ASIC's only published Regulatory Guide on unfair terms pertains to early termination fees

\footnotetext{
${ }^{57}$ ASIC Act $2001 \mathrm{~s} 12 \mathrm{BF}(3)$

58 Jeannie Paterson, Unfair Contract Terms in Australia (Thomson Reuters, 2012) 53 [5.40]

${ }^{59}$ ASIC Act 2001(Cth) s 12BI

${ }^{60}$ Treasury Legislation Amendment (Small Business and Unfair Contract Terms) Act 2015

$<$ http://www.treasury.gov.au/ConsultationsandReviews/Consultations/2015/Extending-unfair-contract-term-protections-to-small-businesses<accessed $25 / 9 / 15>$

${ }^{61}$ ASIC Act 2001(Cth) s12BG(2)

62 Ibid.

${ }^{63}$ e.g H. De Kock, 'Unfair Contract Terms under the Australian Consumer Law', (2013) Dawsons Chambers; D.Svantesson and Loren Holly, 'An Overview and Analysis of the National Unfair Contract Terms Provisions', Bond University ePublications@bond 9-1-2010; J. Paterson, 'The Australian Unfair Contract Terms Law: The Rise Of Substantive Unfairness as a ground for review of standard form Consumer Contracts', Melbourne University
} Law Review [Vol 33] 
for residential loans. ${ }^{64}$

The UCTL provides a list of examples of the kinds of terms of a consumer contract that may be unfair ${ }^{65}$ although no presumption is created that they are unfair. The listed examples may be seen as indicative of unfair terms and often described as a grey list (not a black list).

Two examples of unfair terms provided by s12BH (1) include:

(1) a term that limits, or has the effect of limiting, the evidence one party can adduce in proceedings relating to the contract;

(m) a term that imposes, or has the effect of imposing, the evidential burden on one party in proceedings relating to the contract;

This provision does not limit the operation of the preceding sections but offers a non-exhaustive list of examples of what may constitute unfair terms, but it is an open question whether example (l) would apply to conclusive evidence clauses.

At this point, it is necessary to emphasise that the UCTL's treatment of unfair terms is distinct and separate from any analysis of terms operating as exclusion clauses under consumer protection legislation or common law.

In this respect, Singapore's courts have applied its local UCT legislation to VCE clauses approaching them as exclusion clauses, applying the relevant statutory test of 'reasonableness' to determine their legality. The Singaporean UCT law is very different from its Australian UCTL counterpart. The long title of the Singaporean law impose[s] 'further limits on the extent to which civil liability for breach of contract, or for negligence or other breach of duty, can be avoided by means of contract terms and otherwise'. It is significant that Singapore courts have, in applying its law, upheld the validity of VCE clauses in banking contracts. ${ }^{66}$

\section{The Pacioccocase}

The recent High Court of Australian case of Paciocco v Australia and New Zealand Banking Group Limited ${ }^{67}$ involved a class action in which the plaintiffs claimed that the contractual terms which entitled ANZ to charge the Exception Fees were penalties at common law and equity, that the fees charged were unjust transactions under the National Credit Code, and were unfair terms under the Fair Trading Act1999 (Vic) and the ASIC Act; and that ANZ engaged in unconscionable conduct under these same Acts.

At first instance, the court held that the category of credit card late payment fees charged by ANZ was the only fee which was penal in nature and dismissed the statutory claims. On appeal, the Full Federal Court overturned the finding in relation to the late payment fee, but otherwise upheld Justice Gordon's findings. The Full Federal Court found that the late payment fee was neither extravagant nor unconscionable when compared with the greatest conceivable loss flowing from the breach.

In the High Court, separate reasons were given for judgment in relation to both the penalty and statutory appeal. The High Court found late payment fees charged by Australia and New Zealand Banking Group Limited (ANZ) were not

\footnotetext{
${ }^{64}$ ASIC Regulatory Guide 220 <asic.gov.au/media/1241402/rg220-published-31-august-2011.pdf>

${ }^{65}$ ASIC Act 2001 (Cth) s 12 BH

${ }^{66}$ Consmat Singapore Pte Ltd v Bank of America [1992] 2 SLR 828

${ }^{67}$ [2016] HCA 28,

www.tiprc.org
}

editor@tjprc.org 
unenforceable penalties and did not amount to statutory unconscionable conduct, unjust transactions or unfair contract terms.

At this point, it is not pertinent to VCE clauses to discuss the High Court's definition and views about the operation of penalty clauses ( given that their objectives and functions are markedly different from those of VCE clauses) but the judgment may provide guidance, by analogy, for the future interpretation and application of the relevant legislation relating to VCE clauses.

The issue of whether the ANZ clauses breached statutory norms was addressed at length in the judgment of Justice Gageler. The customers' claims in the representative proceeding included that ANZ has engaged in unconscionable conduct within the meaning of ss 12CB and 12CC of the ASIC Act and ss 8 and 8A of the Fair Trading Act 1999 (Vic) ( applicable at the relevant time) by entering into and implementing the standard contractual stipulation for the charging of the late payment fee. The customers claimed also that the credit card contracts were unjust within the meaning of $\mathrm{s} 76$ of the National Credit Code in Schedule 1 to the National Consumer Credit Protection Act 2009 (Cth) and unfair within the meaning of s $32 \mathrm{~W}$ of the Fair Trading Act and s 12BG of the ASIC Act. His Honour noted that there was no substantial controversy between the parties as to the content of those norms and that the controversy was as to their application. ${ }^{68}$

Matters addressed by Gageler J that may be relevant to VCE clauses are set out under the headings below with the author's own comments about their possible application.

\section{Unconscionable Conduct}

Gageler $\mathbf{J}$ concluded that ANZ had not engaged in unconscionable conduct within the meaning of s 12CB(1) of the ASIC Act when it entered into and then implemented its standard contractual stipulation for the charging of the late payment fee to Mr Paciocco. His Honour found that ANZ did not cause Mr Paciocco to enter into credit card contracts which contained what was, in the language of s $12 \mathrm{CB}(2)(\mathrm{b})$ of the ASIC Act, the 'condition' for the late payment fee; it presented him with standard form contracts on a take-it-or-leave-it basis. ${ }^{69}$ In addition, the existence and amount of the late payment fee were disclosed to Mr Paciocco in the letters, booklets and telephone calls which he received from ANZ. He was able to, and did, understand them. There has never been any suggestion of undue influence or pressure having been exerted on him or of unfair tactics having been used against him. ${ }^{70}$

The judgment highlights the section is concerned with the supplier's (bank's) unconscionable behaviour that results in the consumer entering a contract with it, rather than with the terms of the contract itself. Further, each of the listed matters relating to the conduct of the bank form part of the totality of circumstances that must be taken into account to assess whether the bank has engaged in unconscionable conduct. Therefore, in the absence of such conduct it is unlikely a consumer would be successful in impugning a VCE clause on the basis of unconscionable conduct.

\section{Unfair Terms under Fair Trading Act 1999 (Vic) (Now Repealed) and ASIC Act}

The customer argued that the late payment fee was an "unfair" term under s 32W of the then existing Fair Trading 1999 (which had its equivalent in 12BG of the ASIC Act) claiming that charging the late payment fee caused a significant imbalance in the rights and obligations of ANZ and of Mr Paciocco under the credit card contracts, to the detriment of

\footnotetext{
${ }^{68}$ Paciocco v Australia and New Zealand Banking Group Limited [2016] HCA 28, 54

${ }^{70}$ Ibid

${ }^{69}$ Ibid, 185.
} 
Mr Paciocco as the consumer. Gaegler J. rejected that argument, stating ${ }^{71}$

The significance of that imbalance, they argue, was "demonstrated by the lack of any meaningful relationship between the amount of the late payment fee and the reasonably foreseeable loss which would result to [ANZ] from late payment".

One answer to the argument is that its minor premise has not been established: there was a meaningful relationship between the amount of the late payment fee and the accrual of costs to ANZ from the occurrence of late payment events and that those costs were reasonably foreseeable at the time of contracting. The evidence of Mr Inglis showed that relationship. The more complete answer to the argument is that its major premise is flawed. To demonstrate that the stipulation for payment put ANZ in a situation where it might profit from breaches of contract by a credit card customer without the customer in breach acquiring something in return would not alone be sufficient to allow it to be concluded that the stipulation caused a significant imbalance in the parties' rights and obligations arising under the contract. Even if the stipulation could be characterised as a matter of ordinary language as "penalising the consumer but not the supplier for a breach or termination of the contract", that was only one factor amongst many to be taken into account.

The question of whether a VCE clause in a consumer contract would be approached in the same way under s12BG of the ASIC Act would need to take account of another other factor listed in its three-part threshold test, namely, whether the clause is reasonably necessary to protect the legitimate interests of the supplier (the bank).

\section{EVIDENCE OF USAGE OF VCE CLAUSES IN AUSTRALIA}

There is evidence of limited use of VCE clauses in banking contracts in Australia found in publicly available terms published by banks on their websites and accessible to existing or prospective customers. ${ }^{72}$

In Australia, the range of customers entitled to disclosure of general terms of the banking service is very broad, but not universal given that the application of the Code of Banking Practice (2013) and consumer protection legislation such as the ASIC Act is limited to customers who qualify either as individuals or small businesses. The scope of the other industry code - the ePayments Code- is narrower still, confining itself to individuals and excluding business customers of any kind.

The task of accessing Australian banking terms for these classes of customers is aided by the same industry codes and legislation that mandate disclosure of terms to eligible customers.

The Codes' prescriptions and banks' practices of publishing their terms provide plentiful sources of publicly available online material for detecting and examining VCE clauses (if any) in Australian banking contracts. The class of customer that may be described as big business - in the sense of not being a 'small business' are ineligible for disclosure (or any other benefits) under either of the industry codes, or consumer protection legislation, but will be subject to the banks' specific terms. The latter's terms may be unpublished and confidential between the parties, and are therefore outside the scope of this inquiry. However, there may be some instances where the published terms do not differentiate between small business and big business customers; thereby making the latter's terms available for this analysis.

\footnotetext{
${ }^{71}$ Ibid, 201.

${ }^{72}$ Refer to ANZ terms https://www.anz.com/documents/au/aboutanz/business_transaction_pds.pdf 


\section{SIGNIFICANCE OF THE RESEARCH}

The research conducted so far has established that the use of VCE clauses in Australia remains untested by the courts in relation to consumer banking contracts even though one Australian regulator noted earlier has pre-emptively indicated its hostility towards them. The research shows there are plentiful examples of countries with robust consumer protection regimes that permit the use of VCE clauses in consumer banking contracts, and these may be viewed as providing the sought-after legal justification and appropriate models for Australian banks to follow. Consumer protection legislation dealing with unfair contractual terms present a significant obstacle to their implementation in Australia, but recent Australian case law exemplified in the Pacaccio case dealing with concepts of unfairness and unconscionability in a somewhat different banking context involving credit card charges, opens the way to assessing their prospects for greater use in Australia

There is doctrinal support for the proposition that VCE clauses might be used lawfully in banking contracts in Australia provided they meet the requirements of consumer protection legislation that demands appropriate balancing of interests including demonstrated justification in protecting legitimate interests of the party relying on such clause - in this case, the bank.

In addition to ensuring the wording of the clause is not 'unfair,' particular care would need to be taken in the precontractual stage to ensure adequate notification and appreciation by the customer of the significance of the VCE clause to avoid an allegation of unconscionability in relation to entering the contract. Furthermore, there are several economic models cited in this paper that may justify their use.

Whether banks will ever seek to implement such clauses in Australia may ultimately be decided not by the issue of their lawfulness (even if the courts or legislature decide in their favour) but by market forces and technological developments that move customers away from the manual account-checking obligations that VCE clauses might impose on them. Further work needs to be done on examining the technological impact on bank consumers.

Finally, the trend of consumer focused banking industry codes seems to favour more rather than less reliance on the ability of banks to verify transactions and to detect discrepancies in account transactions.

\section{CONCLUSIONS}

The use of VCE clauses in Australia remains untested by the courts in relation to consumer banking contracts although one Australian regulator has pre-emptively indicated its hostility towards them.

There are plentiful examples of countries with robust consumer protection regimes that permit the use of VCE clauses in consumer banking contracts ${ }^{73}$, and these may be viewed as providing the sought-after legal justification and appropriate models for Australian banks to follow. Consumer protection legislation dealing with unfair contractual terms present a significant obstacle to their implementation in Australia, but recent Australian case law exemplied in the Pacaccio case dealing with concepts of unfairness and unconscionability in a somewhat different banking context involving credit card charges, opens the way to assessing their prospects for greater use in Australia.

It is the tentative conclusion of this paper that VCE clauses might be used lawfully in banking contracts in

\footnotetext{
${ }^{73}$ In the United States, Uniform Commercial Code U.C.C \$4-406; Canadian courts have consistently upheld the validity of verification clauses: see Arrow Transfer Co Ltd v Royal Bank of Canada (1972) 27 DLR (3d) 81 and Columbia Graphophone Co v Union Bank of Canada (1916) 38 OLR; 34
} DLR 743. 
Australia provided they meet the requirements of consumer protection legislation requiring appropriate balancing of interests including demonstrated justification in protecting legitimate interests of the party relying on such clause- in this case, the bank. In addition to ensuring the wording of the clause is not 'unfair,' particular care would need to be taken in the pre-contractual stage to ensure adequate notification of the VCE clause to avoid an allegation of unconscionability in relation to entering the contract. Furthermore, there are several economic models cited in this paper that may justify their use.

Whether banks will ever seek to implement such clauses in Australia may ultimately be decided not by the issue of their lawfulness ( even if the courts or legislature decide in their favour) but by market forces and technological developments that move customers away from the manual account-checking obligations that VCE clauses might impose on them.

Furthermore, the trend of consumer focused banking industry codes seems to favour more rather than less reliance on the ability of banks to verify transactions and to detect discrepancies in account transactions.

\section{REFERENCES}

\section{Articles}

1. M Baiross, ' Conclusive Evidence Clauses in the Court of Appeal: Pertamina Energy Trading Ltd v Credit Suisse' (2007) 25 Singapore Law. Review,136-137.

2. $M$ Braun and $J$ McAndrews and $W$ Roberds and $R$ Sullivan, 'Understanding Risk Management in Emerging Retail Payments',(2008) FRBNY Economic Policy Review, 137, 141.

3. $\quad$ M Burge, 'Apple Pay, Bitcoin and Consumers' (2016) 67 Hastings LJ, 54.

4. P Chynoweth, 'Legal Research' in Andrew Knight and Les Ruddock (eds), Advanced Research Methods in the Built Environment, (Wiley-Blackwell 2008), 31-4.

5. $\quad$ R Cooter and E Rubin, 'A Theory of Loss Allocation for Consumer Payments',(1987) 66 Tex. Rev, 63.

6. H De Kock, 'Unfair Contract Terms under the Australian Consumer Law', (Dawsons Chambers, 2013).

7. D Douglas, 'An examination of the fraud liability shift in consumer card-based payment systems',(2009) 1 Q FRBC Economic Perspectives, 43, 46.

8. F Facciollo, 'Unauthorised Payment Transactions and Who Should Bear the Losses', (2008) Vol 83:2 Chicago-Kent Law Review,

9. C Gillette and S Walt,' Uniformity and Diversity in Payment Systems', (2008) Chicago-Kent Law Review, Vol 83:2.

10. C Hare, 'The duties of bank customers: W(h)ither Tai Hing?' (2012) 23 JBFLP 182.

11. S Harris, 'Introduction to Rethinking Payments Law', (2008) Vol 83, 2 Chicago-Kent Law Review,

12. T Hutchinson, 'The Doctrinal Method: Incorporating Interdisciplinary Methods in Reforming the Law', (2015) 3 Erasmus Law Review 130, 131.

13. F Hayashi and T Moore and R Sullivan,' The Economics of Retail Payment Security' (2015) FRBK Economic Policy Review, $1,6$.

14. C Kahn and W Roberds, 'The Economics of Payment Finality' (2002) Federal Reserve of Atlanta Economic Review, 10. 
15. F Loke,' Framing Contractual Freedom within the precept of Honesty, Reliability and Integrity', (2012) Singapore. Journal of Legal Studies. S, 174,176.

16. J Paterson, 'The Australian Unfair Contract Terms Law: The Rise Of Substantive Unfairness as a ground for review of standard form Consumer Contracts' (2009) 33 Melbourne University Law Review 934.

17. M Snel, 'Source-Usage within doctrinal legal enquiry: choices, problems and challenges' (2014 06) LaM, DOI: 10.5553/REM/.000005.

18. D Svantesson and L Holly, 'An Overview and Analysis of the National Unfair Contract Terms Provisions' (2010) Bond UniversityePublications@bond 9-1-2010

19. A Tyree and J Sheahan, 'Verification Clauses',(2010) 23 JBFLP, 291

\section{Cases}

20. British and North European Bank Ltd v Zalstein [1927] 2 KB 92, 287

21. Consmat Singapore Pte Ltdv Bank of America [1992] 2 SLR 828

22. Greenwood v Martin's Bank Ltd [1933] AC 51

23. Klement v Pencoal(2000) ConvR 54-546.

24. London Joint Stock Bank Ltd v Macmillan and Arthur [1918] AC 777

25. Paciocco v Australia and New Zealand Banking Group Limited [2016] HCA 28

26. Skyring v Greenwood and Cox (1825) 4 B \& C 281

27. Tai Hing Cotton Mill Ltd v Liu Chong Hing Bank Ltd [1986] AC 80.

28. West v Commercial Bank of Australia Ltd (1935) 55 CLR 315

\section{Industry Codes}

29. Code of Banking Practice (2013)

30. ePayments Code

31. Retrieved from http://download.asic.gov.au/media/3798542/epavments-code-published-29-march-2016.pdf

\section{Legislation}

32. Australian Securities Investments and Commission Act 2001 (Cth)

33. Fair Trading Act 1999(Vic) ( repealed)

\section{PHD THESIS}

34. S Booysen, 'Bank Documentation: The standard Terms governing Current Accounts in Singapore; The Customer's duty of care, the unauthorised debit and allocation of risk', (2008) PHD Thesis, National University of Singapore, 161.

\section{Text books}

35. E Ellinger and E Lomnicka and C Hare, Ellinger's Modern Banking Law, (OUP 2009), 244

36. Halsbury's Laws of Australia, (2005), [45-795]. 
37. J Paterson, Unfair Contract Terms in Australia, (Thomson Reuters, 2012)

\section{WEBSITES}

38. Victorian Consumer Affairs. (2010). A guide to the unfair contract terms law. Retrieved from http://www.consumer.vic.gov.au/CA256EB5000644CE/page/Listing-Utility+Buttons

39. ACA submission Annex II: Examples of Unfair Terms in Consumer Contracts. Retrieved from www.treasury.gov.au

40. Australian Treasury. (2015). Treasury Legislation Amendment (Small Business and Unfair Contract Terms) Act 2015. Retrieved from http://www.treasury.gov.au/ConsultationsandReviews/Consultations/2015/Extending-unfair-contract-termprotections-to-small-businesses < accessed 25/9/15>

41. ANZ Business Transaction Accounts Terms and Conditions. Retrieved from https://www.anz.com/documents/au/aboutanz/business_transaction_pds.pdf 
